
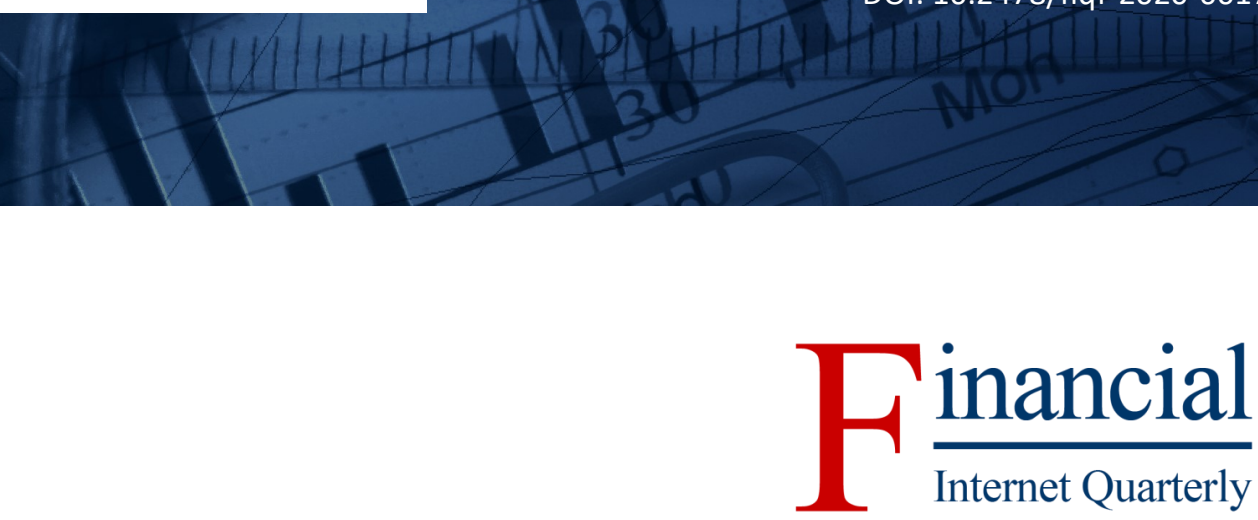

\title{
EXPANDING TAM AND INVESTIGATING THE FACTORS THAT EFFECT CONSUMER INTENTION TO ADOPT MOBILE BANKING IN PALESTINE
}

\section{Haitham Jouda ${ }^{1}$}

Abstract

\begin{abstract}
Purpose The main objective of this study is to expand the technology acceptance model (TAM) by examining the factors affecting the adoption of mobile banking services by the customers of Palestinian banks and to design a comprehensive model based on TAM and TPB and additional constructs. Design/methodology/approach This study used the quantitative approach with cross sectional research design and a questionnaire as a data tool. From the six big cities in Palestine, we surveyed 1000 banking consumers. The samples include different characteristics. For construct relationship analysis this study applied partial least squares (PLS).

Findings The study framework provides a complete view of mobile banking services. This framework takes into consideration more determinants for prediction than other studies on the adoption of innovations. The results of using this model managed to clarify nearly 77.4 percent of the dependent variable (intention to adopt mobile banking service) variation. This is a much greater value than those of the previous studies. Moreover, this study found that the perceived risk has a negative effect on consumers' intention to use mobile banking services. Attitude, facilitating conditions, perceived ease of use, website usability, and perceived trust were identified as the important variables that have a significant positive effect on the consumers' intention to use mobile banking services in Palestine.

Originality/value - the findings can be used by financial institutions and banks to enhance the usage rate of consumers' adoption and to develop their strategies.
\end{abstract}

JEL classification: B30, B31, B32

Keywords: banking e-services, TPB,TAM, technology adoption, attitude, institutions, Palestine

\footnotetext{
${ }^{1}$ Gaza University Palestine, e-mail: H.Jouda@gu.edu.ps, ORCID 0000-0003-1727-5142.
} 


\section{INTRODUCTION}

Mobile banking services (MBS) are a model of the latest developments in technology and are a good example of the rapid penetration of technology in both financial institutions and the banking field, allowing consumers to manage financial transactions independently. Mobile banking service is provided through the internet by using the website or the smartphone applications and it provides simple and advanced services like view account, print account statement, payment of the bills, and fund transfer locally or internationally, etc., to meet the consumers' need at any place or any time (Shaikh \& Karjaluoto, 2014; Lin, 2011; Püschel et al., 2010). Mobile banking service diminishes the costs of financial operations and provides greater convenience and accessibility to consumers (Hoehle, Scornavacca, \& Huff, 2012; Montazemi \& Qahri-Saremi, 2015). Also, good infrastructure and digital channels are required and the banks should have these requirements with high security and access speed (Shaikh \& Karjaluoto, 2014). Banks and other financial institutions have found that financial technology has provided innovations and solutions in the financial field (Gulamhuseinwala, Bull, \& Lewis, 2015) The expansion of mobile service and the internet has specifically enhanced the banking industry and financial technology. It is noteworthy that the number of transactions worldwide increased through mobile payment by around 58.33 per cent from 2014 to 2015 (Dapp \& Slomka, 2015).

Thus, mobile payment systems should be integrated with banking e-services to facilitate the payment process and to avoid the repeating of insert payment details in each process (Boonsiritomachai \& Pitchayadejanant, 2018). An extensive review of existing studies on mobile banking adoption shows that many researchers have already tried to consolidate more than a model and framework to investigate consumers' intention toward MBS (Aboelmaged \& Gebba, 2013; Dineshwar \& Steven, 2013; Martins, Oliveira, \& Popovič, 2014b;). Moreover, in spite of the recent and various extensions of (TAM) in (Davis, Bagozzi, $\&$ Warshaw, 1989), some studies have concentrated only on the variables and construct influencing the use of these banking services or mobile banking applications through an inclusive study that incorporates many factors associated with the important theory such as trust, risk and social influence (Liébana-Cabanillas, SánchezFernández, \& Muñoz-Leiva, 2014; Liébana Cabanillas, 2012) or social influences or subjective norms (Slade, Dwivedi, Piercy, \& Williams, 2015;Bashir \& Madhavaiah, 2015; Phonthanukitithaworn, Sellitto, \& Fong, 2015). On the other hand, Palestine is one of the Middle East countries. It is a developing country and the adoption of mo- bile banking service is still in its early stages and not as high as expected by banks, consumers in banks are still reluctant to adopt and use e-services (Maitah \& Hodrab, 2015). In fact, in several countries and particularly throughout developing countries this problem has been observed (Sharma, Govindaluri, Muharrami, \& Tarhini, 2017). With the success of banks in introducing mobile banking service and justification of the huge investments they spend on banking e-services, there is a need for Palestinian banks to understand clearly the behavior of consumers' and their beliefs towards these services which will certainly lead to their adoption of these services and their continued use. With a view to filling this gap, this study proposes a conceptual model that combines key determinants of consumers' behavior related to the adoption of innovative technology in mobile banking services. The purpose of this study, which uses the TAM model as a framework and additional factors from other theories, is to design a comprehensive framework to determine the important factors that effect consumers' behavior through the relationships between different variables such as perceived ease of use, perceived usefulness, perceived risk, trust, web site usability, facilitating conditions, subjective norms, attitude and intention to use the mobile banking service, etc. These variables will be discussed in detail in the next section.

\section{LITERATURE REVIEW}

In recent years, there has been increasing interest in electronic banking research adoption and acceptance of new technology. Banking e-services (BES) are provided in several methods to the consumers of banking around the world. An example, ATMs, appeared in 1980, and are one of the important services widespread in the world, making BES very convenient. Therefore, the MBS are expected to be an important channel for consumers' to conduct financial transactions (Nasri \& Charfeddine, 2012). However, MBS provides several benefits for consumers' such as time-saving and speed of managing accounts, and low handling fees. Despite the benefits offered by this service, there is a wide range of customers reluctant to adopt this service because of fears that it is unsafe and unreliable (Chaouali, Ben Yahia, Souiden, et al., 2016; M.-C. C. Lee, 2009). Previous studies have focused largely on the individual or multiple variables that limit or inhabit customer behavior to adopt the MBS. For instance trust (Chaouali, Ben Yahia, Souiden, et al., 2016; Yousafzai, Pallister, \& Foxall, 2009; Yu, Balaji, \& Khong, 2015), risk (Ali Abdallah Alalwan, Dwivedi, Rana, \& Algharabat, 2018; K. C. Lee \& Chung, 2009; Martins et al., 2014), security (Giovanis, 
Binioris, \& Polychronopoulos, 2012; Law, 2007; Weir, Douglas, Carruthers, \& Jack, 2009), privacy (Chen, 2013; Law, 2007; Mukhtar, 2015), and website usability (Aboobucker \& Bao, 2018; Casaló, Flavián, \& Guinaliu, 2008; Hasbullah et al., 2016). However, the researchers in all these studies have concentrated on the factors which hinder the MBS usage, no past studies have searched subjective norms, trust, risk, privacy, and website usability in one model together with an average impact that inhibits greatly the usage of MBS. In recent years, there is fast prevalence in the usage of internet banking which has led to a great effect in total and specifically in the banking sector (K. C. Lee \& Chung, 2009; Riffai, Grant, \& Edgar, 2012). For this reason, web technology is considered to be the new channel or method to provide the new services and keep the consumers' (Martins et al., 2014). In the past studies, the researchers have used several hypotheses and concepts to clarify the MBS usage and various findings have resulted from these studies. But on the other hand, deficient security, privacy, and trust of the consumers represent significant inhibiting factors to use MBS. However, the majority of past studies have concentrated on variants that have an impact on MBS usage, few past studies handled various inhibiting factors at the same time. According to Rodrigues, Oliveira, \& Costa, (2016) behavioral intent is determined by the perceived decision made by online internet banking clients, in which consequently they react to online shopping in a positive or negative way. In the literature, there are numerous studies that have employed many theories to enable them to understand the factors that affect usage of MBS between bank consumers (Nasri \& Charfeddine, 2012). Theories that clarify the link between consumer attitude, and intention are the theory of planned behavior (TPB), technology acceptance model (TAM), and theory of reasoned action (TRA), some of them were involved in common models. According to (Ajzen \& Fishbein, 1977), it was concluded that beliefs have an impact on attitudes that influence intentions in a direct way and in the end, the actions are created and all of that forms the theory of reasoned action (TRA). Moreover, $70 \%$ of the differences in the consumers' intentions are explained through a unified theory of acceptance and use of technology (UTAUT), which is presented by the (Viswanath Venkatesh Michael G. Morris, Venkatesh, Morris, Davis, \& Davis, 2003). According to (Davis et al., 1989) TAM was proven to be a better effective theoretical model in demonstrating the information technology adoption by the consumers, therefore, it is considered as an exclusion of the theories mentioned above in social psychology. The TAM goal is to enable the researcher to predict the acceptance and usage of internet technology, in which perceived ease of use (PEOU) and perceived use- fulness (PU) are considered essential concepts affecting the attitudes (ATT) which consequently have an impact on the behavioral intention (BI) which leads to use or adoption of a new method, technology or channel according to (Davis et al., 1989; Viswanath Venkatesh Michael G. Morris, 2003; Wang, Wang, Lin, \& Tang, 2018). TAM was used in past studies to predict the adoption and usage of BES in several countries such as Greece (Giovanis et al., 2012) Malay and Chinese (Nor, Sutanonpaiboon, \& Mastor, 2010), Tunisia (Nasri \& Charfeddine, 2012), India (Mukherjee, Kumar, Sinha, Lama, \& Saha, 2016) Iran (Hanafizadeh, Keating, \& Khedmatgozar, 2014).

\section{RESEARCH PROBLEM}

Successful implementation of mobile banking service needs a high level of consumer adoption of these services that justifies the investments and supports the bank in this regard (Akhlaq \& Ahmed, 2013; Bashir \& Madhavaiah, 2015). Palestine is one of the Middle East countries. It is a developing country and the adoption of mobile banking service is still in its early stages and not as high as expected by banks, consumers in banks are still reluctant to adopt and use e-services (Maitah \& Hodrab, 2015). In fact, in several countries and particularly throughout developing countries this problem has been observed (Sharma, Govindaluri, Muharrami, \& Tarhini, 2017). An example is the report of (comScore Data Mine, 2012) which found that only $25 \%$ of internet users worldwide entered the banking e-services website and showed that the lowest utilization rate for e-service was in Africa and the Middle East (8.8\%), South America (25.1\%) Europe (37.8\%), and the highest rate was in the USA (45\%). Nevertheless, few studies (Khrewesh, 2011; Maitah \& Hodrab, 2015) have been performed in Palestine to examine the consumer's behavior toward mobile banking services. Therefore, there is a need to study the factors affecting the decision of users and their intentions towards MBS in Palestine. The results of this study could provide important solutions and clarifications about the beliefs and intentions of users not only in Palestine but also in the surrounding countries and countries of the Middle East because these countries are similar in culture and way of thinking.

\section{RESEARCH MODEL AND HYPOTHESES}

TAM is found to have sufficient explanatory power and the researcher can add more factors or moderators to improve it (Sun \& Zhang, 2006). The current study model expands the TAM model and scope of the MBS adoption decision by combining five external latent variables such as perceived risk from perceived risk theory, 
Figure 1: Proposed Conceptual Model

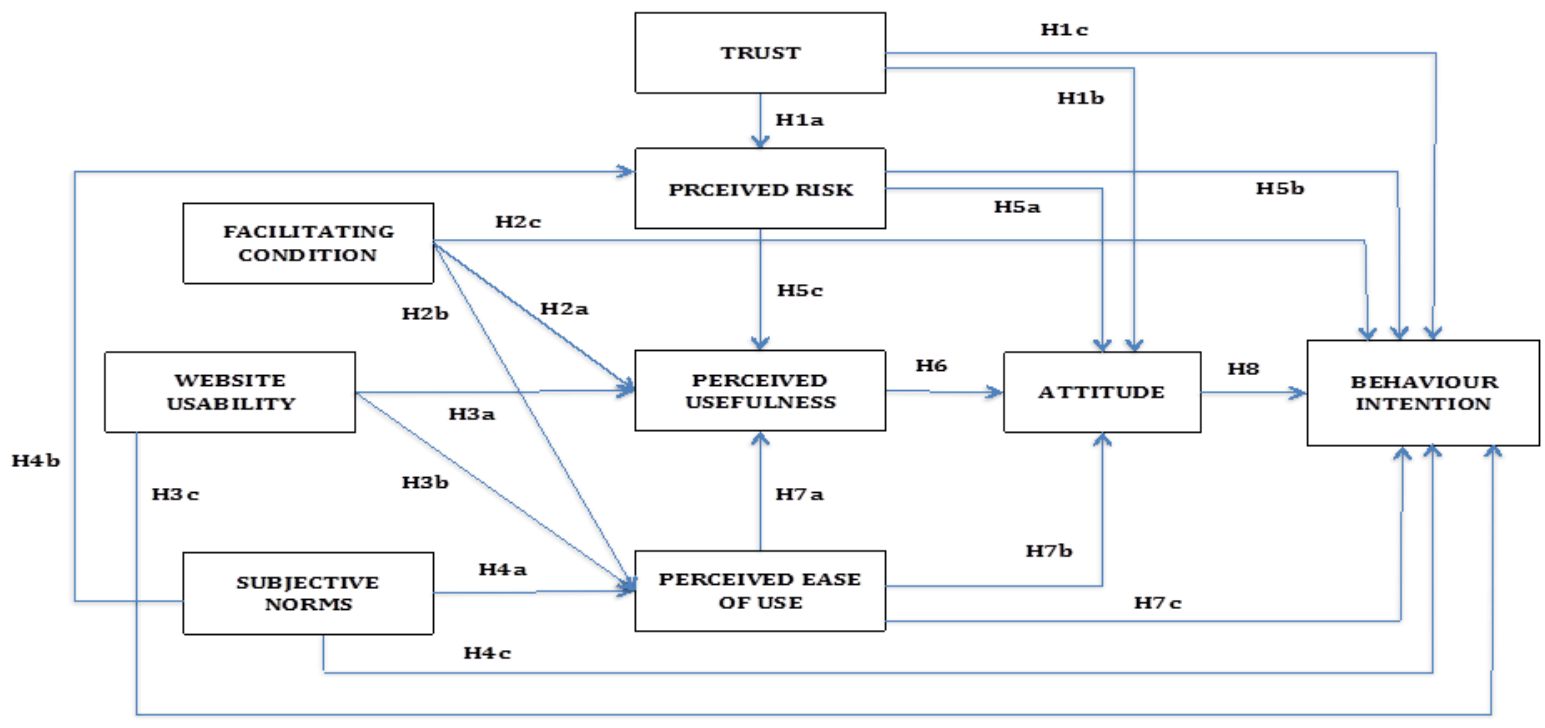

Source: Own work

bles such as perceived risk from perceived risk theory, perceived trust, website usability, facilitating conditions and subjective norms form (TPB) and the role of attitude as mediator variables toward MBS as shown in Figure 1. These variables will be discussed in detail in the next section.

\section{Perceived TRUSt (PT)}

The construct perceived trust refers to the dependence of someone on another despite the risk. The researchers identify trust as a determinant of decisionmaking to encourage the consumers to use new technologies (Currall \& Judge, 1995). To build the confidence of the consumers in MBS, the consumers should have trust in the security of the money transaction method and that the data introduced to the webapp and mobile app are safe and that no one can get it (Suh \& Han, 2003). Trust is considered to be an essential factor because it has what the researcher called separation both "spatial and temporal" between the online bank and the consumers (Grabner-Kraeuter, 2002). So, regarding MBS, the lack of trust in mobile banking resulted from the fact that lack of personal offline contact, which generates the natural services, results in low consumer acceptance (Chaouali, Ben Yahia, \& Souiden, 2016). According to Balasubramanian, Konana, \& Menon,(2003) the trust in the nature of the MBS is formed through the relationship between the con- sumer and the features of the MBS like privacy, safety, reliability, suitability, safe information exchange, and efficient transactions. The researchers have made several studies to check the effect of the trust on the intention of consumers to adopt MBS (Jouda, Abu, Obaid, Abu, \& Awaja, 2020,Chaouali, Ben Yahia, Souiden, et al., 2016; Yousafzai et al., 2009; Yu et al., 2015; Zhou, 2011) and these studies proved that trust has an essential role in making decisions and encouraging the consumers to use mobile banking services. Moreover, intention is greatly determined by several factors especially perceived risk and trust (Aboobucker \& Bao, 2018; H. M. Jouda \& Raju, 2018; Kesharwani \& Singh Bisht, 2012; Yousafzai et al., 2009).Therefore, we proposed the following hypotheses:

H1a. Trust has a positive impact on consumers' perceived risk to use mobile banking.

H1b. Trust has a positive impact on consumers' attitude to use mobile banking.

H1c Trust has a positive impact on consumers' intention to use mobile banking.

\section{FACILITATING CONDITION (FC)}

Facilitation conditions (FC) indicate availability of required resources such as software, hardware, and technology infrastructure, which support the banking eservices (Khalifa \& Shen, 2008; Venkatesh, Thong, \& Xu, 
2012; Yang, Whitefield, \& Bhanot, 2005). Individuals who have resources and experience are expected to use the mobile banking service more than the individual who has fewer resources (Di Benedetto, Calantone, \& Zhang, 2003). The mobile banking services require that consumers have the skills, such as using the computer or smart mobile device, to connect to and use the internet (Martins et al., 2014). As a result, if a consumer doesn't have the devices and certain skills, therefore he/she will not use the mobile banking service (Hong, Thong, Moon, \& Tam, 2008; Zhou, Lu, \& Wang, 2010). In TAM3 model, FCs are designed as antecedents to perceived ease of use and perceived usefulness (Faqih \& Jaradat, 2015). Maruping, Bala, Venkatesh, \& Brown, (2017) found that the consumer intention to use the MBS was affected by the FC construct. Also FCs have effect on consumers' attitudes to use MBS (Crabbe, Standing, Standing, \& Karjaluoto, 2009; Yuen, Yeow, \& Lim, 2015). Therefore, we proposed the following hypotheses:

H2a. Facilitating condition has a positive impact on consumers' perceived usefulness of mobile banking.

$H 2 b$. Facilitating condition has a positive impact on consumers' perceived ease of use in mobile banking.

H2c. Facilitating condition has a positive impact on consumers' intention to use mobile banking.

\section{WEBSITE USABILITY (WU)}

Barnes \& Vidgen, (2002) found that usability is identified as all aspects concerning the perception, usage, interactions of the clients with the bank app or website, whether the clients can use the website easily, whether it has a proper shape and design, and how the clients concentrate on the design to encourage its adoption and usage. The purpose of having a beautiful and proper design is to have an interesting and attractive MBS wepapp or website so the design will reflect the level of clients' gratification (Ahmad \& Al-Zu'bi, 2011). Moreover, the design of the webapp has a significant role that influences the clients' gratification in both the MBS websites and online marketing websites in addition to payment websites (Aboobucker \& Bao, 2018; Alam \& Yasin, 2010; Hasbullah et al., 2016). Moreover, according to Yoon \& Steege, (2013) usability factors like perceived ease of use (PEOU) and perceived usefulness (PU) have a positive impact on the client's awareness to encourage them to use the MBS. In other studies, the website usability effect is integrated such as the information introduced through the BES website is a significant factor that has an impact on BES use in Finland according to (Pikkarainen, Pikkarainen, Karjaluoto,
\& Pahnila, 2004). The website usability can enhance the clients' knowledge about the MBS and it enables the clients to adopt the MBS. Moreover, the usability of the website is considered to be an essential factor in determining the relation between the clients and the MBS (Aboobucker \& Bao, 2018; Hasbullah et al., 2016)

Therefore, we proposed the following hypotheses:

H3a. Website usability has a positive impact on consumers' perceived usefulness of mobile banking.

H3b. Website usability has a positive impact on consumers' perceived ease of use of mobile banking.

H3c. Website usability has a positive impact on consumers' intention to use mobile banking.

\section{SUBJECTIVE NORMS (SNS)}

Subjective norms (SN) are defined as the perception of the individual that the majority of individuals around him may influence him towards a specific behavior that he or she should not do (Ajzen \& Fishbein, 1975). Individuals often act based on their understanding of what other important individuals believe they should do. SNs have been considered to be more important before or in the initial step of implementing innovation when the consumer has insufficient experience to develop her/her own attitudes. (Chua, 1980; Taylor \& Todd, 1995) point out that important friends, family, and peers/colleagues of consumers are groups that are likely to affect the decision of adoption. As a result, the same must be done in the banking e-services context. Al-Qeisi, (2009) found that SN has an insignificant influence on consumers' intentions in Jordanian banks. Alternatively, Nor \& Pearson, (2008) found that SNs have a positive and significantly influence on the intention to adopt and use technology in Malaysia. Additionally, only a few researches in the banking eservices have investigated the role of family influence on SNs (Nor, Shanab, \& Pearson, 2008; Ya-Yueh \& Fang, 2004). Previous studies have integrated SNs with the TAM model and found that SNs influence the perceived usefulness and behavioral intention (Abbad, 2013; Kesharwani \& Tripathy, 2012). SNs have positive and direct effects on both perceived usefulness and consumer's intention to use MBS (Mehrad \& Mohammadi, 2017). Furthermore, Kesharwani and Singh Bisht, (2012) have found that the $\mathrm{SN}$ has a significant negative effect on the perceived risk (PR). These studies conclude that family has an important impact on SNs. In empirical studies, the SNs refer to the importance of social impacts on non-users of the mobile banking service. Moreover, the SNs are a significant antecedent of the adoption intention, attitude, performance 
cedent of the adoption intention, attitude, performance expectancy, facilitating conditions, and effort expectancy (Liang, 2016).

Therefore, we proposed the following hypotheses:

H4a. Subjective norms have a positive effect on consumers' perceived ease of use of mobile banking.

$H 4 b$. Subjective norms have a negative effect on consumers' perceived risk to use mobile banking.

H4c. Subjective norms have a positive effect on consumers' intention to use mobile banking.

\subsubsection{PERCEIVED RISK (PR)}

Perceived risk (PR) refers to the degree of risk ingrained in technology and innovation (Ram \& Sheth, 1989). Perceived Risk is often created among consumers because of the uncertainty associated with the degree of differences between client judgment and the actual result of mobile banking service use that may fail to deliver expected results (Im, Mason, \& Houston, 2007). Researches on technology adoption context introduce empirical evidence that consumers' perception about the risk is significant when thinking about banking e-services (Laforet \& Li, 2005; Yang et al., 2005). Firstly, in the context of mobile banking service, perceived risk is a significant factor because of concerns about privacy and security (Luarn \& Lin, 2005). Secondly, consumer's fears of losing a list of PINs may also pose security concerns and threats for him (Kuisma, Laukkanen, \& Hiltunen, 2007). Finally, some clients also fear or are concerned about the hackers who may control and access their bank account details and using this information transfer the money to third parties (Akturan \& Tezcan, 2012; Hanafizadeh, Keating, \& Khedmatgozar, 2014; Luarn \& Lin, 2005; Poon, 2007). Previous researchers have found that the PR is the significant factor affecting trust (Al-Gahtani, 2011; Liao, Rebecca Yen, \& $\mathrm{Li}, 2011$ ) and affecting the MBS adoption (Ha, Canedoli, Baur, \& Bick, 2012; Mishra \& Bisht, 2013; Sohail \& AlJabri, 2014) and also has negative impact on both attitude and intention of consumers to use the MBS (Chiou \& Shen, 2012; Kesharwani \& Tripathy, 2012) and negative influence on perceived usefulness (Cheng, Lam, \& Yeung, 2006; K. C. Lee \& Chung, 2009).

Therefore, we proposed the following hypotheses:

H5a. Perceived risk has a negative effect on consumers' attitude toward mobile banking.

H5b. Perceived risk has a negative effect on consumers' intention to use mobile banking.
H5c. Perceived risk has a negative effect on consumers' perceived usefulness of mobile banking.

\section{Perceived usefulness (PU)}

Perceived Usefulness (PU) refer to the degree that the individual assumes that using a particular service or technology may improve her/his skills and functionality. PU in TAM model is considered one of the important constructs and has a significant influence on consumers' intention to accept a new system (Davis et al., 1989; Adams, Nelson, \& Todd, 1992; Pikkarainen et al., 2004) and also previous researchers have indicated that there is a significant impact of PU on consumers' attitude and intention (Chiou \& Shen, 2012; M.-C. C. Lee, 2009; Sum Chau \& Ngai, 2010). Additionally, PU is that the system provides the benefits they aspire to, and improves the functions they perform, therefore the ease of use is not enough alone or is an advantage if the system does not meet their ambitions and requirements (Davis, 1989). As a consequence, if the consumers feel that the MBS is useful then they are more likely to use this service and may encourage other consumers. Therefore, according to the TAM model, we assume that PU has a positive impact on consumers' intention to use the MBS. Thus, we proposed the following hypotheses:

H6. Perceived usefulness has a positive effect on consumers' attitude toward mobile banking.

\section{PeRCeIVED EASE OF USE (PEOU)}

According to Davis (1989), PEOU is "the degree to which a person believes that using a particular system would be effortless." Previous studies have provided evidence that PEOU is another important factor affecting consumers' intention and has a positive impact on consumers' attitude to adopt a new system (Adams et al., 1992; Davis et al., 1989; Deng, Lu, Wang, Zhang, \& Wei, 2010; Gefen et al., 2008; Luarn \& Lin, 2005) and to use MBS (Chiou \& Shen, 2012; Giovanis, Binioris, \& Polychronopoulos, 2012; Sum Chau \& Ngai, 2010). Many studies and TAM assume that PEOU is an important factor influencing the intention to adopt ITs, through PU directly or indirectly (Abbad, 2013; Çelik, 2008; Davis et al., 1989; Kesharwani \& Tripathy, 2012). In addition, PEOU has a positive effect on PU (Davis et al., 1989; Gefen et al., 2008). According to TAM, the direct effect of the relationship between the PEOU and PU increases and shows clearly as the interest increases with PEOU, which will affect performance and improve it and reduce the required effort to perform the same work. Similarly, when 
the banks provide MBS in a distinctive and easy to use way, it will certainly encourage potential consumers to use these services. Therefore, in line with TAM, and previous studies, we proposed the following hypotheses:

H7a. Perceived ease of use has a positive effect on consumers' perceived usefulness of mobile banking

H7b. Perceived ease of use has a positive effect on consumers' attitude toward mobile banking.

H7c. Perceived ease of use has a positive effect on consumers' intention to use mobile banking.

\section{ATTITUdE (ATT)}

According to Ajzen and Fishbein (1980), it is possible to predict the attitude of the individual by knowing his/ her beliefs on a particular subject with a high degree of accuracy and that this will lead to the way that can convince the individual either to adopt a specific attitude or change his/her attitude. Prior research on understanding and investigating the consumers' attitude towards the MBS mainly depended on recognizing MBS as an advanced technology service, therefore, they strived to investigate the factors that affect consumers' attitude toward adopting the new innovation (Hassan, Mansour, Eljelly, \& Abdullah, 2016). Several researchers have found that the main factor influencing the decisions of consumers to use the new service or new technology is the perceptions of consumers about innovation (Lean, Zailani, Ramayah, \& Fernando, 2009; Papies \& Clement, 2008; Zhou, 2011). The theory of diffusion innovation (IDT) (Rogers, 2003) introduced a set of innovative features that may affect the decision of consumers to adopt innovation. Many prior studies have investigated constructs of IDT in the diffusion and adoption of new technologies and they have consistently found that these features, especially PU, and PEOU are the most commonly identified constructs for the adoption and diffusion innovation of existing internet service (Koenig-Lewis, Palmer, \& Moll, 2010; Papies \& Clement, 2008; Tan, Chong, Loh, \& Lin, 2010). Previous studies provide empirical evidence that the attitude of consumers affects their intentions to use the MBS and mediate the effect of perceived usefulness and perceived ease of use on intention (Aboelmaged \& Gebba, 2013; Bashir \& Madhavaiah, 2015; Chiou \& Shen, 2012; M.-C. C. Lee, 2009).

Therefore, we proposed the following hypothesis:

H8. Attitude has a positive effect on consumers' intention to use banking e-services.

\section{METHODOLOGY}

In the present study, to get the required data that will be used to validate the proposed model and hypotheses, this study used the quantitative approach with cross sectional research design and the questionnaire as a data tool. The population of this study is all consumers with a bank account, and the selected sample size is 1000 respondents and this sample was selected based on simple random sampling. The data were collected by using the questionnaires with a self-administered method that was developed and distributed to elicit responses from the consumers of Palestinian banking about their, beliefs, attitudes and intentions towards mobile banking. Appendex 1 shows all 36 items that are used to measure all the constructs of the proposed model in this study. Firstly, the PU construct, having six items are taken from (AldásManzano, Lassala-Navarré, Ruiz-Mafé, \& Sanz-Blas, 2009) and Cheng et al., (2006) Nor et al., (2010) and Giovanis et al., (2012). The PEOU construct, having five items, are taken from Nor et al., (2010) and Aldás-Manzano et al., (2009) and Cheng et al., (2006) and Giovanis et al., (2012). The attitude construct, has five items and these items are taken from Suh and Han, (2002) and (Ya-Yueh and Fang, (2004) and Cheng et al., (2006) and Grabner-Kräuter and Faullant, (2008). Secondly, the additional constructs (TR, $\mathrm{PR}, \mathrm{FC}, \mathrm{WU}, \mathrm{SN}, \mathrm{T})$ trust has six items that are taken from (Gefen, Karahanna, \& Straub, 2003). The construct of PR has seven items adapted from Featherman and Pavlou, (2003) and these items cover the main PR dimensions. Venkatesh et al. (2012) four items were used to measure the FC construct. The construct web site usability, having five items are taken from (Barnes \& Vidgen, 2002; Jaruwachirathanakul \& Fink, 2005). As for SN, three items were taken from Hung et al. (2003). Thirdly, the BI construct, having five items are taken from Walker and Johnson, (2006) and Al-Sukkar (2005) and Shih and Fang (2004), and Suh and Han (2002). All the constructs items of the proposed model were scored on a 5-point Likert scale with anchors ranging from " 1 " (strongly disagree) to " 5 " (strongly agree). Finally, six convergent questions were assigned to demographic variables: gender, age group, living area, level of education, internet experience, and computer experience. Taking into consideration that the language of participants is Arabic and to avoid the influence of cultural and linguistic differences and to ensure that the all items are clear and understandable, we applied the method of back translation to convert the questionnaire to Arabic as recommended by (Brislin, 1976). 


\section{DATA ANALYSIS TOOLS}

The Software SMART 3.0 PLS-SEM "structural equation modeling technique" and the software (SPSS) Package for Social Sciences Version 20.0 were used in this study to test the model and there are some scale items that have been modified to the specific conditions of this study.

\section{MEASUREMENT MODEL}

According to Chin, Marcolin, and Newsted, (2003) the AVE square should have a value greater than the correlations between constructs to confirm that the discriminant validity is adequate between the variables or constructs.

Table 1: Discriminant validity

\begin{tabular}{|l|l|l|l|l|l|l|l|l|l|}
\hline Constrct & ATT & BI & FC & PEOU & PR & PT & PU & SN & WU \\
\hline ATT & $\mathbf{0 . 8 9 2}$ & & & & & & & & \\
\hline BI & 0.833 & $\mathbf{0 . 9 1 5}$ & & & & & & & \\
\hline FC & 0.645 & 0.670 & $\mathbf{0 . 8 4 1}$ & & & & & & \\
\hline PEOU & 0.493 & 0.553 & 0.438 & $\mathbf{0 . 7 8 8}$ & & & & & \\
\hline PR & -0.583 & -0.641 & -0.472 & -0.354 & $\mathbf{0 . 8 8 5}$ & & & & \\
\hline PT & 0.603 & 0.561 & 0.450 & 0.397 & -0.365 & $\mathbf{0 . 8 3 0}$ & & & \\
\hline PU & 0.731 & 0.642 & 0.470 & 0.386 & -0.440 & 0.582 & $\mathbf{0 . 8 5 4}$ & & \\
\hline SN & 0.310 & 0.266 & 0.173 & 0.119 & -0.193 & 0.140 & 0.287 & $\mathbf{0 . 8 3 9}$ & \\
\hline WU & 0.625 & 0.584 & 0.434 & 0.331 & -0.401 & 0.356 & 0.315 & 0.172 & $\mathbf{0 . 9 2 4}$ \\
\hline
\end{tabular}

Source: This study, computed by author

Table 2 demonstrates that for all constructs, the AVE square root is higher than the correlations among constructs in the study model (Hair Jr, Hult, Ringle, \& Sarstedt, 2016). It emphasizes that the discriminant should be obtained for all constructs. To assure the suitability of the measurement model, the researchers assess individual elements like reliability, internal consistency and the convergent and discriminant model and all results indicate that the measurement model is suitable.

Factor loadings of all items, and the construct AVE value and Cronbach's Alpha (CA) are demonstrated in Table 3. To analyze the reliability of the indicator, factor loading of each items must be higher than 0.7 to be considered statistically significant as recommended by (Chin et al., 2003). The bootstrapping method is conducted with 500 resamples to obtain a t-statistic and the result shows that all are loading statistically significant at $1 \%$. There are two items from PR construct PR1 0.682, PR2 0.315 and one item from the ATT construct ATT3 0.569 and one item from $\mathrm{BI}$ construct $\mathrm{BI} 30.627$ and finally, one item from the WU construct WU2 0.0229 was excluded because it resulted in a lower factor loading than as from our initial attempt. After that, we conduct the bootstrapping method again and the results show that each item has factor loadings $>0.7$ and indicates the internal consistency (Hair Jr et al., 2016).We proofed the composite reliability (CR) and (CA) to assure the accuracy of the constructs. The most famous feature is CA which represents an evaluation of reliability which is determined by the intercorrelation of indicator and according to it each indicator has an equal reliability (Henseler et al., 2009). As shown in Table 3 , the internal consistency is assured because all constructs' values of CR and CA are higher than the expected lower limit of 0.7. The AVE was performed to assure convergent validity since AVE is the value of the indicator variance and is calculated for the main elements and it should be higher than 0.5 , because of this, the basic variables clarify more than half its indices difference (Henseler et al., 2009). In Table 2, the convergent validity is assured because AVE for all constructs are greater than the lower value of 0.5 (Hair Jr et al., 2016)

\section{RESULTS AND FINDINGS}

\section{RESPONDENTS' PROFILES AND CHARACTERIS- TICS}

Banking customers completed six hundred twelve valid questionnaires on mobile banking service. As shown in Table 1: $64.1 \%$ of the respondents were male and $35.9 \%$ females. The results indicate that the (20-29) age group obtained a large percentage of the correct sample 
(44.8\%). The qualification level shows (40.8\%) of respondents had a bachelor's degree. In terms of mobile banking experience, it was noted that a large group of respondents (45.9\%) had observed that they haven't experience followed by $(25.3 \%)$ with more than three years of experience.

Table 2: Construct Factor loading, AVE, Composite Reliability and Cronbachs Alpha

\begin{tabular}{|c|c|c|c|c|c|}
\hline Construct & Item & Factor loading & AVE & $\begin{array}{l}\text { Composite } \\
\text { Reliability }\end{array}$ & Cronbachs Alpha \\
\hline \multirow[t]{3}{*}{ Attitude } & ATT1 & 0.936387 & \multirow[t]{3}{*}{0.795983} & \multirow[t]{3}{*}{0.921187} & \multirow[t]{3}{*}{0.871452} \\
\hline & ATT2 & 0.88189 & & & \\
\hline & ATT4 & 0.856387 & & & \\
\hline \multirow[t]{3}{*}{ Behavior intention } & $\mathrm{BI} 1$ & 0.899036 & \multirow[t]{3}{*}{0.837003} & \multirow[t]{3}{*}{0.939013} & \multirow[t]{3}{*}{0.902441} \\
\hline & $\mathrm{B} 12$ & 0.944456 & & & \\
\hline & $\mathrm{B} \mid 4$ & 0.900415 & & & \\
\hline \multirow[t]{4}{*}{ Facilitating conditions } & FC1 & 0.784974 & \multirow[t]{4}{*}{0.708119} & \multirow[t]{4}{*}{0.906332} & \multirow[t]{4}{*}{0.865499} \\
\hline & FC2 & 0.833777 & & & \\
\hline & FC3 & 0.911349 & & & \\
\hline & FC4 & 0.830993 & & & \\
\hline \multirow{4}{*}{$\begin{array}{l}\text { Perceived } \\
\text { ease of Use }\end{array}$} & PEOU1 & 0.756993 & \multirow[t]{4}{*}{0.621509} & \multirow[t]{4}{*}{0.8678} & \multirow[t]{4}{*}{0.797262} \\
\hline & PEOU2 & 0.788503 & & & \\
\hline & PEOU3 & 0.808956 & & & \\
\hline & PEOU4 & 0.798029 & & & \\
\hline \multirow[t]{4}{*}{ Perceived Risk } & PR3 & 0.776109 & \multirow[t]{4}{*}{0.783339} & \multirow[t]{4}{*}{0.934994} & \multirow[t]{4}{*}{0.905808} \\
\hline & PR4 & 0.936249 & & & \\
\hline & PR5 & 0.881981 & & & \\
\hline & PR6 & 0.936249 & & & \\
\hline \multirow[t]{4}{*}{ Perceived Trust } & PT1 & 0.727732 & \multirow[t]{4}{*}{0.688208} & \multirow[t]{4}{*}{0.897468} & \multirow[t]{4}{*}{0.858213} \\
\hline & PT2 & 0.775639 & & & \\
\hline & PT3 & 0.915806 & & & \\
\hline & PT4 & 0.88483 & & & \\
\hline \multirow[t]{3}{*}{ Perceived Usefulness } & PU1 & 0.835165 & \multirow[t]{3}{*}{0.729778} & \multirow[t]{3}{*}{0.890098} & \multirow[t]{3}{*}{0.821388} \\
\hline & PU2 & 0.852295 & & & \\
\hline & PU3 & 0.874886 & & & \\
\hline \multirow[t]{4}{*}{ Subjective Norms } & SN1 & 0.778693 & \multirow[t]{4}{*}{0.703984} & 0.904384 & 0.863291 \\
\hline & SN2 & 0.935911 & & & \\
\hline & SN3 & 0.847665 & & & \\
\hline & SN4 & 0.784289 & & & \\
\hline Website Usability & WU1 & 0.91921 & 0.853363 & 0.920879 & 0.828303 \\
\hline & WU3 & 0.928321 & & & \\
\hline
\end{tabular}


Table 3: Demographic Respondents Profile ( $\mathrm{N}=612)$

\begin{tabular}{|c|c|c|c|}
\hline Demographic characteristics & item & Frequency & Per cent $\%$ \\
\hline Gender & $\begin{array}{l}\text { Male } \\
\text { Female }\end{array}$ & $\begin{array}{l}392 \\
220\end{array}$ & $\begin{array}{l}64.1 \\
35.9\end{array}$ \\
\hline Age & $\begin{array}{l}\text { Less than } 20 \text { years } \\
20-29 \text { years } \\
30-39 \text { years } \\
40-49 \text { years } \\
50 \text { years and above }\end{array}$ & $\begin{array}{l}24 \\
274 \\
200 \\
95 \\
19\end{array}$ & $\begin{array}{r}3.9 \\
44.8 \\
32.7 \\
15.5 \\
3.1\end{array}$ \\
\hline Qualification & $\begin{array}{l}\text { Up to High School } \\
\text { Diploma } \\
\text { Bachelor } \\
\text { Master } \\
\text { PhD }\end{array}$ & $\begin{array}{c}106 \\
97 \\
250 \\
91 \\
68\end{array}$ & $\begin{array}{l}17.3 \\
15.8 \\
40.8 \\
14.9 \\
11.1\end{array}$ \\
\hline Mobile banking experience. & $\begin{array}{l}\text { haven't used } \\
\text { Up to } 1 \text { year } \\
\text { 1-2 years } \\
\text { 2-3 years } \\
\text { More than } 3 \text { years }\end{array}$ & $\begin{array}{l}281 \\
36 \\
56 \\
84 \\
155\end{array}$ & $\begin{array}{l}45.9 \\
5.9 \\
9.2 \\
13.7 \\
25.3\end{array}$ \\
\hline Living area & $\begin{array}{l}\text { Gaza Strip } \\
\text { West Bank }\end{array}$ & $\begin{array}{l}339 \\
273\end{array}$ & $\begin{array}{l}55.4 \\
44.6\end{array}$ \\
\hline
\end{tabular}

Source: Own elaboration

(44.8\%). The qualification level shows (40.8\%) of respondents had a bachelor's degree. In terms of mobile banking experience, it was noted that a large group of respondents (45.9\%) had observed that they haven't experience followed by (25.3\%) with more than three years of experience.

\section{STRUCTURAL MODEL}

A structural model can be estimated through checking the coefficients of the path " $\beta$ ", that detects the power of the link among independent variables and the dependent variable and the value of (R2), which demonstrates the whole difference identified by the independent variables according to Al-Somali et al., (2009). The finding of the structural model is demonstrated in Figure 2. The value of the path coefficient is presented associated with its own $t$ -value and the path of the non-significant. Figure 2 demonstrated the eight independent variables (PT, PR, PU, PEOU, FC, WU and SN) together illustrated $77.4 \%$ of the variance on intention. Moreover, Figure 2 shows that the four independent variables (PR, PT, PU, PEOU) together illustrated $66.9 \%$ of the variance on attitude. 
Figure 2: Results of path analysis

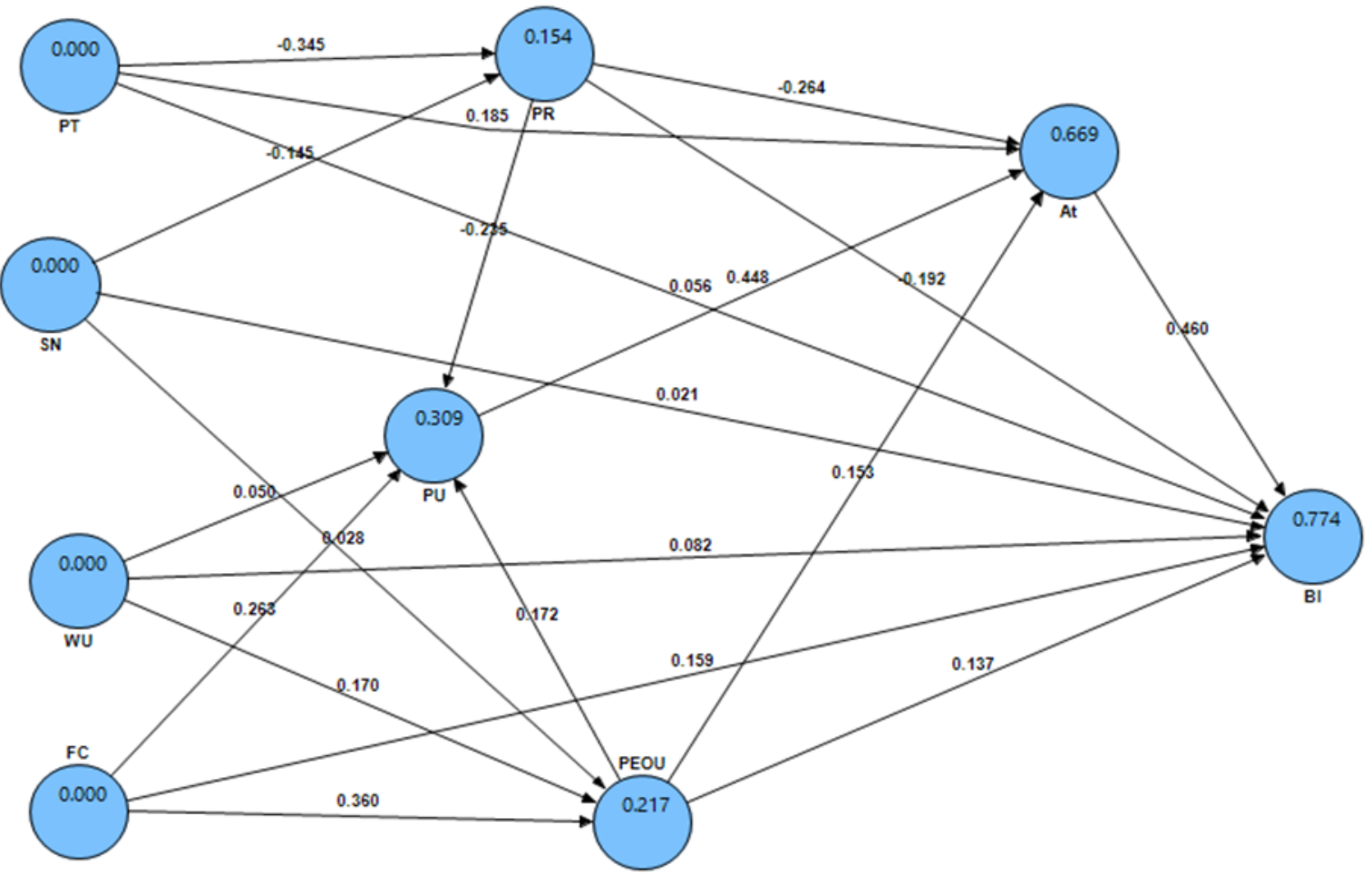

Source: Own elaboration

\section{HYPOTHESIS TESTING}

Table 4 shows the hypothesis testing results and observations of each hypothesized significance path. The finding indicates that the intention of consumers to use the MBS is anticipated through the ATT $(\beta=0.460$, $p<0.00001)$, TR $(\beta=0.0560, p<0.05), P R(\beta=-0.192, p<$ $0.00001), F C(\beta=0.158, p<0.00001), W U(\beta=0.0824$, $p<0.0013)$, and PEOU $(\beta=0.136, p<0.00001)$. These variables demonstrate $77.4 \%$ of the variance of intention to use BES (R2=0.774). Therefore, hypotheses, $\mathrm{H} 1 \mathrm{c}, \mathrm{H} 2 \mathrm{c}$, $\mathrm{H} 3 \mathrm{c}, \mathrm{H} 5 \mathrm{~b}, \mathrm{H} 7 \mathrm{c}$, and $\mathrm{H} 8$ are all supported. ATT is anticipated by $\operatorname{TR}(\beta=0.184, p<0.00001)$, PR $(\beta=-0.264$, $p$ $<0.00001)$, PU $(\beta=0.448, p<0.00001)$ and PEOU $(\beta=0.153$, $p<0.00001)$ and together show $66.9 \%$ of the overall variation in the ATT. This result validated the hypotheses $\mathrm{H} 1 \mathrm{~b}$,
$\mathrm{H} 5 \mathrm{a}, \mathrm{H} 6$, and $\mathrm{H7b}$. As seen in the Figure 2 and Table 4, PT $(\beta=-0.344, p<0.00001)$ has negative influence on $P R$, and the hypothesis $\mathrm{H} 1 \mathrm{a}$ is validated. $\mathrm{FC}(\beta=0.262, p<0.00001)$ and PEOU $(\beta=0.171, p<0.00003)$ has a positive influence and $P R(\beta=-0.235, p<0.00001)$ has a negative influence on $\mathrm{PU}$. Hence, the hypotheses $\mathrm{H} 2 \mathrm{a}, \mathrm{H} 7 \mathrm{a}$ and $\mathrm{H} 5 \mathrm{c}$ are validated. Additionally, FC $(\beta=0.359, p<0.00001)$, and WU $(\beta=0.170, p<0.00012)$ have significant influence on PEOU. Hence, hypotheses $\mathrm{H} 2 \mathrm{~b}$ and $\mathrm{H} 3 \mathrm{~b}$ are validated. $\mathrm{SN}$ $(\beta=0.027, p>0.05)$ has no significant influence on PEOU and also $S N(\beta=0.020, p>0.05)$ has no significant influence on PR. Hence, hypothesis $\mathrm{H} 4 \mathrm{~b}$ is validated. Finally, WU $(\beta=0.049, p>0.05)$ has no significant influence on $P U$. Hence, the hypothesis $\mathrm{H} 3 \mathrm{a}$ is not supported. 
Table 4: Structural model assessment and hypothesis testing

\begin{tabular}{|c|c|c|c|c|c|c|}
\hline Hypotheses & $\begin{array}{l}\text { Hypothesis } \\
\text { Path }\end{array}$ & $\begin{array}{l}\text { Path } \\
\text { Coefficient } \\
\text { (Beta) }\end{array}$ & $\begin{array}{l}\text { Standard } \\
\text { Error } \\
\text { (STERR) }\end{array}$ & $\begin{array}{l}\text { T Statistics } \\
\text { (|O/STERR|) }\end{array}$ & $\begin{array}{l}\text { Sig Value (1 } \\
\text {-tailed) }\end{array}$ & Supported \\
\hline $\mathrm{H} 1 \mathrm{a}$ & PT -> PR & -0.34474 & 0.046468 & 7.418946 & 0.00001 & Yes \\
\hline $\mathrm{H} 1 \mathrm{~b}$ & PT $->$ At & 0.184726 & 0.031771 & 5.814297 & 0.00001 & Yes \\
\hline $\mathrm{H} 1 \mathrm{c}$ & PT -> BI & 0.056006 & 0.035036 & 1.598539 & 0.05 & Yes \\
\hline $\mathrm{H} 2 \mathrm{a}$ & $F C->P U$ & 0.262557 & 0.054735 & 4.796908 & 0.00001 & Yes \\
\hline $\mathrm{H} 2 \mathrm{~b}$ & FC $->$ PEOU & 0.359614 & 0.04439 & 8.101263 & 0.00001 & Yes \\
\hline $\mathrm{H} 2 \mathrm{c}$ & $\mathrm{FC}->\mathrm{BI}$ & 0.158733 & 0.031331 & 5.066372 & 0.00001 & Yes \\
\hline H3a & $W U->P U$ & 0.049903 & 0.04264 & 1.170317 & 0.1212 & No \\
\hline $\mathrm{H} 3 \mathrm{~b}$ & WU $->$ PEOU & 0.170143 & 0.045995 & 3.699161 & 0.00012 & Yes \\
\hline $\mathrm{H} 3 \mathrm{c}$ & WU -> BI & 0.082413 & 0.027251 & 3.024179 & 0.0013 & Yes \\
\hline $\mathrm{H} 4 \mathrm{a}$ & SN -> PEOU & 0.02788 & 0.046384 & 0.601082 & 0.274 & No \\
\hline $\mathrm{H} 4 \mathrm{~b}$ & SN $->P R$ & -0.144809 & 0.040138 & 3.607744 & 0.00017 & Yes \\
\hline $\mathrm{H} 4 \mathrm{C}$ & $\mathrm{SN}->\mathrm{BI}$ & 0.020616 & 0.02117 & 0.973843 & 0.1653 & No \\
\hline $\mathrm{H} 5 \mathrm{a}$ & PR $->$ At & -0.264097 & 0.030046 & 8.789848 & 0.00001 & Yes \\
\hline $\mathrm{H} 5 \mathrm{~b}$ & PR $->B I$ & -0.192063 & 0.030575 & 6.281739 & 0.00001 & Yes \\
\hline $\mathrm{H} 5 \mathrm{c}$ & $P R->P U$ & -0.235168 & 0.05061 & 4.646638 & 0.00001 & Yes \\
\hline H6 & $\mathrm{PU} \rightarrow \mathrm{At}$ & 0.44832 & 0.041544 & 10.791463 & 0.00001 & Yes \\
\hline $\mathrm{H7a}$ & PEOU -> PU & 0.171768 & 0.042149 & 4.075252 & 0.00003 & Yes \\
\hline $\mathrm{H} 7 \mathrm{~b}$ & PEOU $->$ At & 0.153349 & 0.029228 & 5.246664 & 0.00001 & Yes \\
\hline $\mathrm{H} 7 \mathrm{c}$ & PEOU -> BI & 0.136626 & 0.031409 & 4.349893 & 0.00001 & Yes \\
\hline $\mathrm{H} 8$ & $A t->B I$ & 0.460035 & 0.039783 & 11.563584 & 0.00001 & Yes \\
\hline
\end{tabular}

Source: Own elaboration

Table 5: Attitude Mediation effect

\begin{tabular}{|c|c|c|c|c|c|c|}
\hline Relationship & $\begin{array}{l}\text { Direct Effect } \\
\text { (Ind-Med) }\end{array}$ & $\begin{array}{l}\text { Indirect } \\
\text { Effect }\end{array}$ & $\begin{array}{l}\text { Total } \\
\text { Effect }\end{array}$ & $\begin{array}{l}\text { Significance of } \\
\text { Mediation }\end{array}$ & $\begin{array}{l}\text { T Statistics } \\
\text { of Mediation }\end{array}$ & Status \\
\hline PR $->$ ATT $\rightarrow$ BI & -0.2641 & -0.1215 & -0.3856 & 0.0000 & -6.9969 & $\begin{array}{l}\text { Approved } \\
\text { (Partial) }\end{array}$ \\
\hline PT $->$ ATT $\rightarrow>$ BI & 0.1847 & 0.0850 & 0.2697 & 0.0000 & 5.2009 & $\begin{array}{l}\text { Approved } \\
\text { (Partial) }\end{array}$ \\
\hline $\mathrm{PU}->\mathrm{ATT}->\mathrm{BI}$ & 0.4483 & 0.2062 & 0.6546 & 0.0000 & 7.8870 & $\begin{array}{l}\text { Approved } \\
\text { (Partial) }\end{array}$ \\
\hline POEU $->$ ATT $->$ BI & 0.1533 & 0.0705 & 0.2239 & 0.0000 & 4.7699 & $\begin{array}{l}\text { Approved } \\
\text { (Partial) }\end{array}$ \\
\hline
\end{tabular}


The study has taken the necessary steps proposed to assess the effects of mediation as well as the use of the necessary tools which are known as the process and these tools are the same as advised by (Hayes, 2013). It also relied on Sobel's mediation to apply it and observe the consequences. Table 5 shows the results of mediation, its direct and indirect impact, as well as its importance. Table 5 shows the values of the total effect path coefficient between -0.385 (PR) and 0.654 (PU) but it does not exceed this range. The direct effect is largely scattered between the values of $-0.264(P R)$ to $0.448(P U)$ and there is a significant difference between them, but all these relations are important and could not be ignored. Then, when calculating the indirect effect, it ranged from -0.121 (PR) to 0.206 (PU) and is found at a large level associated with the experimental value. These results show that the Total effect outweighs the direct effect much more than the indirect effect. We conclude from this that the effect of mediation exists in partial effect and the fact that the importance of all relations in a significant indirect way ensures that.

\section{Discussion}

The main aim of the present study is to investigate the factor that affects consumers' perceptions, attitudes, and behavior intention toward MBS in Palestine. The study found as shown in Figure 1 which presents practical support for the proposed model and that confirmed the majority of the relationship. The explanatory power of the structural model is $\left(R_{2}=77.4 \%\right)$ with the intention to use $\mathrm{MBS}$ and $\left(\mathrm{R}_{2}=66.9 \%\right)$ for the ATT. Overall, the model of the study is capable to define the change in the attitudes of users and their intentions towards MBS in Palestine. The ATT has a strong effect $(\beta=0.46)$ and appears to be the main positive determinant of consumer intentions to use MBS, followed by FC ( $\beta=0.159)$, PEOU $(\beta=0.137)$, WU $(\beta=0.082)$ and PT $(\beta=0.056)$. Based on this, the results correspond to previous studies that emphasized the importance and role of the ATT in interpreting consumer intention as one of the most important factors (Akturan \& Tezcan, 2012; Chiou \& Shen, 2012; M.C. C. Lee, 2009; Lin, 2011). Although, PR ( $\beta=-0.192)$ exerts a negative influence on ATT and intention to use MBS. This result is similar to the results in (Aboobucker \& Bao, 2018b; Chiou \& Shen, 2012; Kesharwani \& Tripathy, 2012) which found that the PR almost has a negative influence on ATT and intention to use MBS. Although the PU ( $\beta=$ $0.448)$ and PEOU $(\beta=0.15)$ had a positive influence on the $A T T$, and PEOU $(\beta=0.14)$ a direct significant effect on the intention to use MBS. Similar results achieved by (Chiou \& Shen, 2012; Giovanis et al., 2012; M.-C. C. Lee, 2009). As shown in Table 5 , the findings can be interpreted by the mediation role played by the ATT in the study model, which reveals that in the existence of ATT the PR, PT, PU, and PEOU have direct and indirect effects on intention. The effect of PU, PEOU, PR, and PT are mediated partially through attitude entirely across the position. Moreover, according to TAM, the findings of this study indicate that PU $(\beta=0.21)$ has a strong influence on BI through ATT, followed by PR $(\beta=0.12)$ has a direct and indirect effect on the intention through ATT. Similar results were achieved by Chiou and Shen (2012) and Suh and Han (2002). Therefore, it can be explained that PU and PR are more influential in shaping the attitude of consumers towards use of MBS than the PEOU.

\section{RESEARCH CONTRIBUTION}

As with any study, this study has an important contribution, especially on banking consumer behavior over the internet. These contributions are summarized in two parts: theoretical, and managerial contributions, which will be present below:

\section{THEORETICAL CONTRIBUTION}

With regard to the construction of theory, we proposed a new trend for research on mobile banking service (MBS) adoption by examining the features of the mobile banking and banking e-services environment through providing a combined framework. The framework of this study develops a new model by adding new constructs with (TAM) from (TPB) and other theories and utilizing them with the model of this study. Noteworthy are the new variables particular to MBS and technology of the online environment, these variables are, trust, risk, facilitating condition, website usability, subjective norms, and these variables are harmonious with the TAM and TPB variables. In fact, the current study adds wealth and insight into the comprehension of individual responses towards adoption of MBS and its use. In addition, this study provides a contribution in the field of electronic banking and related studies and other studies in the field of electronic commerce and shopping through the internet as well, since the variables are similar but there is a difference in the environment so this model can be applied in similar environments. In addition, the role of the individual and the organizational and societal roles and their influence on the behavioral intention have been interpreted by the TPB but there is a clear failure to interpret the beliefs that affect the attitude of the consumers, so to overcome this weakness we used the PU and PEOU from the TAM model, which related to attitudinal beliefs and these two models are integral approaches. However, there is a scarcity of studies which concentrate on how these beliefs of PU, PEOU are shaped. Therefore, we add new variables 
PR, Trust, FC, WU and SN into the TAM model. Also, this contributes to the literature that use of TAM can determine the impacts of exogenous variables on TAM. Furthermore, experimental findings indicate that the combination of TAM with a construct from TPB and other external constructs gave a better illustrative power, which may introduce a basis to combine other acceptance models of technology. Finally, this study involved attitude within the TAM model and the findings indicate that the attitude is the main factor that affects consumers' intention to adopt MBS. Also, the attitude was found to mediate the influence of PU, PEOU, PT and PR on intention, thus contributing to existing research that supports the significance of attitude in interpreting consumers' acceptance of technology.

\section{PRACTICAL IMPLICATIONS}

The present study has many practical implications that are discussed below. The findings of this study show that when consumers believe that the TR, WU, FC, and MBS characteristics are suitably managed, the consumers' inclination to adopt and use MBS will increase. Also, attitude plays a main important role in impacting consumers' intention toward the MBS. Hence, banks should concentrate more on the improvement of a positive attitude about MBS amongst likely consumers. Additionally, PR, $T R$, and WU are the main concern that influences the customer's intention to adopt MBS. Therefore, managers of banks should assure that the MBS platform is technically robust and sound, and high-security processes are per- formed to reduce risk in the MBS system. Also, they should show more interest in building better strategies for trust to make consumers feel more secure with MBS. Finally, the usability, features of the website and valueservices will encourage consumers to adopt and use MBS. Therefore, developers of the mobile banking systems should develop systems that have enough technical savvy with valuable features to fulfill consumers' needs, which will certainly increase adoption rates. These requirements are necessary for the banks to maintain their actual users and to expand the base of potential consumers.

\section{LIMITIONS AND RECOMMENDATION FOR FU- TURE RESEARCH}

The present study has some limitations. First, this study did not take into account the consumers' characteristics based on their gender, income, education, internet experience, and living areas. The comparison of these layers may show various behavioral traits towards MBS, which can exhibit more important information and achievable results. Second, many specific factors such as awareness, self-efficacy, technophobia, user privacy, and bank support for consumers are factors that should be investigated in future studies. Finally, the preliminary data are used in this study to draw a conclusion. Future studies should use longitudinal data and observe the behavioural changes among customers and their concerns in separate periods, which will give a more thorough understanding to the phenomenon.

\section{REFERENCES:}

Abbad, M.M. (2013). E-banking in Jordan. Behaviour and Information Technology, 32(7), 681-694. https:// doi.org/10.1080/0144929X.2011.586725

Aboelmaged, M.G., Gebba, T.R. (2013). Mobile Banking Adoption : An Examination of Technology Acceptance Model and Theory of Planned Behavior. International Journal of Business Research and Development, 2(1), 35-50. https:// doi.org/10.1007/978-3-531-92534-9_12

Aboobucker, I., Bao, Y. (2018). What Obstructs Customer Acceptance of Internet Banking? Security and Privacy, Risk, Trust and Website Usability and the Role of Moderators. Journal of High Technology Management Research, (xxxx), 0-1. https://doi.org/10.1016/j.hitech.2018.04.010

Adams, D.A., Nelson, R.R., Todd, P.A. (1992). Perceived Usefulness, Ease of Use, and Usage of Information Technology: A Replication. MIS Quarterly, 227-247.

Ahmad, A.M.K., Al-Zu'bi, H.A. (2011). E-banking Functionality and Outcomes of Customer Satisfaction: an Empirical Investigation. International Journal of Marketing Studies, 3(1), 50.

Ajzen, I., Fishbein, M. (1975). Belief, Attitude, Intention and Behavior: An Introduction to Theory and Research. Reading, MA: Addison-Wesley.

Ajzen, I., Fishbein, M. (1977). Attitude-behavior Relations: A Theoretical Analysis and Review of Empirical Research. Psychological Bulletin, 84(5), 888-918. https://doi.org/10.1037/0033-2909.84.5.888 
Ajzen, I., Fishbein, M. (1980). Understanding Attitudes and Predicting Social Behaviour.

Akhlaq, A., Ahmed, E. (2013). The Effect of Motivation on Trust in the Acceptance of Internet Banking in a Low Income Country. International Journal of Bank Marketing, 31(2), 115-125. https://doi.org/10.1108/02652321311298690

Akturan, U., Tezcan, N. (2012). Mobile Banking Adoption of the Youth Market: Perceptions and Intentions. Marketing Intelligence \& Planning, 30(4), 444-459.

Al-Gahtani, S.S. (2011). Modeling the Electronic Transactions Acceptance Using an Extended Technology Acceptance Model. Applied Computing and Informatics, 9(1), 47-77.

Al-Qeisi, K.I. (2009). Analyzing the Use of UTAUT Model in Explaining an Online Behaviour: Internet Banking Adoption. Brunel University Brunel Business School PhD Theses.

Al-Somali, S.A., Gholami, R., Clegg, B. (2009). An Investigation into the Acceptance of Online Banking in Saudi Arabia. Technovation, 29(2), 130-141.

Al-Sukkar, A.S. (2005). The Application of Information Systems in the Jordanian Banking Sector: a Study of the Acceptance of the Internet.

Alalwan, Ali A, Dwivedi, Y.K., Rana, N.P., \& Simintiras, A.C. (2016). Jordanian Consumers' Adoption of Telebanking: Influence of Perceived Usefulness, Trust and Self-efficacy. International Journal of Bank Marketing, 34(5), 690-709.

Alalwan, Ali Abdallah, Dwivedi, Y.K., Rana, N.P., Algharabat, R. (2018). Examining Factors Influencing Jordanian Customers' Intentions and Adoption of Internet Banking: Extending UTAUT2 with Risk. Journal of Retailing and Consumer Services, 40 (July), 125-138. https://doi.org/10.1016/j.jretconser.2017.08.026

Alam, S.S., Yasin, N.M. (2010). An Investigation into the Antecedents of Customer Satisfaction of Online Shopping. Journal of Marketing Development and Competitiveness, 5(1), 71-78.

Aldás-Manzano, J., Lassala-Navarré, C., Ruiz-Mafé, C., Sanz-Blas, S. (2009). Key Drivers of Internet Banking Services Use. Online Information Review, 33(4), 672-695.

Balasubramanian, S., Konana, P., Menon, N.M. (2003). Customer Satisfaction in Virtual Environments: A study of Online Investing. Management Science, 49(7), 871-889.

Barnes, S.J., Vidgen, R.T. (2002). An Integrative Approach to the Assessment of E-commerce Quality. J. Electron. Commerce Res., 3(3), 114-127.

Bashir, I., Madhavaiah, C. (2015). Consumer Attitude and Behavioural Intention Towards Internet Banking Adoption in India. Journal of Indian Business Research, 7(1), 67-102. https://doi.org/10.1108/JIBR-02-2014-0013

Boonsiritomachai, W., Pitchayadejanant, K. (2018). Determinants Affecting Mobile Banking Adoption by Generation Y Based on the Unified Theory of Acceptance and Use of Technology Model Modified by the Technology Acceptance Model concept. Kasetsart Journal of Social Sciences, 1-10. https://doi.org/10.1016/j.kjss.2017.10.005

Brislin, R.W. (1976). Comparative Research Methodology: Cross-cultural Studies. International Journal of Psychology, 11(3), 215-229.

Casaló, L.V, Flavián, C., Guinal\’\iu, M. (2008). The Role of Satisfaction and Website Usability in Developing Customer Loyalty and Positive Word-of-mouth in the E-banking Services. International Journal of Bank Marketing, 26(6), 399-417.

Çelik, H. (2008). What Determines Turkish Customers' Acceptance of Internet Banking? International Journal of Bank Marketing, 26(5), 353-370. https://doi.org/10.1108/02652320810894406

Chaouali, W., Ben Yahia, I., Souiden, N. (2016). The Interplay of Counter-conformity Motivation, Social Influence, and Trust in Customers' Intention to Adopt Internet Banking Services: The Case of an Emerging Country. Journal of Retailing and Consumer Services, 28, 209-218. https://doi.org/10.1016/j.jretconser.2015.10.007

Chen, C. (2013). Perceived Risk, Usage Frequency of Mobile Banking Services. Managing Service Quality: An International Journal, 23(5), 410-436. https://doi.org/10.1108/MSQ-10-2012-0137

Cheng, T.C.E., Lam, D.Y.C., Yeung, A.C.L. (2006). Adoption of Internet Banking: an Empirical study in Hong Kong. Decision Support Systems, 42(3), 1558-1572. 
Chin, W.W., Marcolin, B.L., Newsted, P.R. (2003). A Partial Least Squares Latent Variable Modeling Approach for Measuring Interaction Effects: Results from a Monte Carlo Simulation Study and an Electronic-mail Emotion/adoption Study. Information Systems Research, 14(2), 189-217.

Chiou, J.-S., Shen, C.-C. (2012). The Antecedents of Online Financial Service Adoption: the Impact of Physical Banking Services on Internet Banking Acceptance. Behaviour \& Information Technology, 31(9), 859-871.

Chua, E.K. (1980). Consumer Intention to Deposit at Banks: An Empirical Investigation of its Relationship with Attitude, Normative Belief and Confidence. Academic Exercise, Faculty of Business Administration, National University of Singapore.

Crabbe, M., Standing, C., Standing, S., Karjaluoto, H. (2009). An Adoption Model for Mobile Banking in Ghana. International Journal of Mobile Communications, 7(5), 515-543.

Cruz, P., Barretto Filgueiras Neto, L., Munoz-Gallego, P., Laukkanen, T. (2010). Mobile Banking Rollout in Emerging Markets: Evidence from Brazil. International Journal of Bank Marketing, 28(5), 342-371.

Currall, S.C., Judge, T.A. (1995). Measuring Trust between Organizational Boundary Role Persons. Organizational Behavior and Human Decision Processes, 64(2), 151-170.

Dapp, T., Slomka, L. (2015). Fintech Reloaded--Traditional Banks as Digital Ecosystems. Publication of the German Original.

Davis, F.D. (1989). Information Technology Introduction, 13(3), 319-340.

Davis, F.D., Bagozzi, R.P., Warshaw, P.R. (1989). User Acceptance of Computer Technology: a Comparison of Two Theoretical Models. Management Science, 35(8), 982-1003.

Deng, Z., Lu, Y., Wang, B., Zhang, J., Wei, K.K. (2010). An Empirical Analysis of Factors Influencing Users' Adoption and Use of Mobile Services in China. International Journal of Mobile Communications, 8(5), 561-585.

Di Benedetto, C.A., Calantone, R.J., Zhang, C. (2003). International Technology Transfer: Model and Exploratory Study in the People's Republic of China. International Marketing Review, 20(4), 446-462.

Dineshwar, R., Steven, M. (2013). An Investigation on Mobile Banking Adoption and Usage: A Case Study of Mauritius. Proceedings of 3rd Asia-Pacific Business Research Conference, 3(February), 1-21.

Faqih, K.M.S., Jaradat, M.I.R.M. (2015). Assessing the Moderating Effect of Gender Differences and Individualism-collectivism at Individual-level on the Adoption of Mobile Commerce Technology: TAM3 Perspective. Journal of Retailing and Consumer Services, 22, 37-52. https://doi.org/10.1016/j.jretconser.2014.09.006

Featherman, M.S., Pavlou, P.A. (2003). Predicting E-services Adoption: a Perceived Risk Facets Perspective. International Journal of Human-Computer Studies, 59(4), 451-474.

Gefen, D., Benbasat, I., Pavlou, P. (2008). A Research Agenda for Trust in Online Environments. Journal of Management Information Systems, 24(4), 275-286.

Gefen, Karahanna, \& Straub. (2003). Trust and TAM in Online Shopping: An Integrated Model. MIS Quarterly, $27(1), 51$. https://doi.org/10.2307/30036519

Giovanis, A.N., Binioris, S., Polychronopoulos, G. (2012). An Extension of TAM Model with IDT and Security/privacy Risk in the Adoption of Internet Banking Services in Greece. EuroMed Journal of Business, 7(1), $24-53$.

Grabner-Kraeuter, S. (2002). The Role of Consumers' Trust in Online-shopping. Journal of Business Ethics, 39(1-2), 43-50.

Grabner-Kräuter, S., Faullant, R. (2008). Consumer Acceptance of Internet Banking: the Influence of Internet Trust. International Journal of Bank Marketing, 26(7), 483-504.

Gulamhuseinwala, I., Bull, T., Lewis, S. (2015). FinTech is Gaining Traction and Young, High-income Users are the Early Adopters.

Ha, K.-H., Canedoli, A., Baur, A. W., Bick, M. (2012). Mobile Banking_Insights on its Increasing Relevance and Most Common Drivers of Adoption. Electronic Markets, 22(4), 217-227.

Hair Jr, J.F., Hult, G.T.M., Ringle, C., Sarstedt, M. (2016). A Primer on Partial Least Squares Structural Equation Modeling (PLSSEM). Sage Publications. 
Hanafizadeh, P., Keating, B.W., Khedmatgozar, H.R. (2014). A Systematic Review of Internet Banking Adoption. Telematics and Informatics. https://doi.org/10.1016/j.tele.2013.04.003

Hartwick, J., Barki, H. (1994). Explaining the Role of User Participation in Information System Use. Management Science, 40 (4), 440-465.

Hasbullah, N.A., Osman, A., Abdullah, S., Salahuddin, S.N., Ramlee, N.F., Soha, H.M. (2016). The Relationship of Attitude, Subjective Norm and Website Usability on Consumer Intention to Purchase Online: An Evidence of Malaysian Youth. Procedia Economics and Finance, 35, 493-502.

Hassan, I., Mansour, F., Eljelly, A.M.A., \& Abdullah, A. M. A. (2016). Review of International Business and Strategy For Authors Consumers' Attitude Towards E-banking Services in Islamic Banks: the Case of Sudan. International Business and Strategy Iss, 26(2), 244-260. https://doi.org/10.1108/RIBS-02-2014-0024

Hayes, A.F. (2013). Modellübersicht Mediation/Moderation (process-macro). https://doi.org/978-1-60918-230-4

Henseler, J., Ringle, C.M., Sinkovics, R.R. (2009). The Use of Partial Least Squares Path Modeling in Iternational Marketing. In: New challenges to international marketing (pp. 277-319). Emerald Group Publishing Limited.

Hoehle, H., Scornavacca, E., Huff, S. (2012). Three Decades of Research on Consumer Adoption and Utilization of Electronic Banking Channels: A Literature Analysis. Decision Support Systems, 54(1), 122-132.

Hong, S.-J., Thong, J.Y.L., Moon, J.-Y., Tam, K.-Y. (2008). Understanding the Behavior of Mobile Data Services Consumers. Information Systems Frontiers, 10(4), 431.

Im, S., Mason, C.H., Houston, M.B. (2007). Does Innate Consumer Innovativeness Relate to New Product/service Adoption Behavior? The Intervening Role of Social Learning via Vicarious Innovativeness. Journal of the Academy of Marketing Science, 35(1), 63-75.

Jaruwachirathanakul, B., Fink, D. (2005). Internet Banking Adoption Strategies for a Developing Country: the Case of Thailand. Internet Research, 15(3), 295-311.

Jouda, H., Abu, A., Obaid, T., Abu, S., Awaja, A. (2020). Mobile Banking Adoption : Decomposed Theory of Planned Behavior with Perceived Trust, 1-10. https://doi.org/https://ssrn.com/abstract=3660403

Jouda, H.M., Raju, V. (2018). The Role of Trust on Consumer Intention Towards Mobile Banking in Palestine, 3(9), $203-210$.

Kesharwani, A., Singh Bisht, S. (2012). The Impact of Trust and Perceived Risk on Internet Banking Adoption in India: An Extension of Technology Acceptance Model. International Journal of Bank Marketing, 30(4), 303-322.

Kesharwani, A., \& Tripathy, T. (2012). Dimensionality of Perceived Risk and Its Impact on Internet Banking Adoption: An Empirical Investigation. Services Marketing Quarterly, 33(2), 177-193.

Khalifa, M., Shen, K.N. (2008). Drivers for Transactional B2C M-commerce Adoption: Extended Theory of Planned Behavior. Journal of Computer Information Systems, 48(3), 111-117.

Khrewesh, A.H. (2011). E-banking Adoption Model in Palestine, 1-208. Retrieved from http://www.scholar.najah.edu Koenig-Lewis, N., Palmer, A., Moll, A. (2010). Predicting Young Consumers' Take up of Mobile Banking Services. International Journal of Bank Marketing, 28(5), 410-432.

Kuisma, T., Laukkanen, T., \& Hiltunen, M. (2007). Mapping the Reasons for Resistance to Internet Banking: A Means-end Approach. International Journal of Information Management, 27(2), 75-85.

Laforet, S., Li, X. (2005). Consumers' Attitudes Towards Online and Mobile Banking in China. International Journal of Bank Marketing, 23(5), 362-380.

Law, K. (2007). Impact of Perceived Security on Consumer Trust in Online Banking. Thesis.

Lean, O.K., Zailani, S., Ramayah, T., Fernando, Y. (2009). Factors Influencing Intention to Use E-government Services Among Citizens in Malaysia. International Journal of Information Management, 29(6), 458-475.

Lee, K.C., Chung, N. (2009). Understanding Factors Affecting Trust in and Satisfaction with Mobile Banking in Korea: A Modified DeLone and McLean's Model Perspective. Interacting with Computers, 21(5-6), 385-392. 
Lee, M.-C. C. (2009). Factors Influencing the Adoption of Internet Banking: An Integration of TAM and TPB with Perceived Risk and Perceived Benefit. Electronic Commerce Research and Applications, 8(3), 130-141. https://doi.org/10.1016/ j.elerap.2008.11.006

Liang, C.C. (2016). Subjective Norms and Customer Adoption of Mobile Banking: Taiwan and Vietnam. In: Proceedings of the Annual Hawaii International Conference on System Sciences (Vol. 2016-March, pp. 1577-1585). https://doi.org/10.1109/ HICSS.2016.199

Liao, C.-H., Rebecca Yen, H., Li, E.Y. (2011). The Effect of Channel Quality Inconsistency on the Association between E-service Quality and Customer Relationships. Internet Research, 21(4), 458-478.

Liébana-Cabanillas, F., Sánchez-Fernández, J., Muñoz-Leiva, F. (2014). The Moderating Effect of Experience in the Adoption of Mobile Payment Tools in Virtual Social Networks: The m-Payment Acceptance Model in Virtual Social Networks (MPAM-VSN). International Journal of Information Management, 34(2), 151-166. https://doi.org/10.1016/ j.ijinfomgt.2013.12.006

Liébana Cabanillas, F.J. (2012). El papel de los sistemas de pago en lo nuevos entornos electrónicos. Granada: Universidad de Granada.

Lin, H.-F. (2011). An Empirical Investigation of Mobile Banking Adoption: The Effect of Innovation Attributes and knowledgebased trust. International Journal of Information Management, 31(3), 252-260.

Luarn, P., Lin, H.-H. (2005). Toward an Understanding of the Behavioral Intention to Use Mobile Banking. Computers in Human Behavior, 21(6), 873-891.

Maitah, M., Hodrab, R. (2015). An Empirical Study of Critical Factors of Electronic Banking Adoption for Banking Sector in Palestine. Modern Applied Science, 9(9), 78-92. https://doi.org/10.5539/mas.v9n9p78

Martins, C., Oliveira, T., Popovič, A. (2014). Understanding the Internet Banking Adoption: A Unified Theory of Acceptance and Use of Technology and Perceived Risk Application. International Journal of Information Management, 34(1), 1-13. https://doi.org/10.1016/j.ijinfomgt.2013.06.002

Maruping, L.M., Bala, H., Venkatesh, V., Brown, S.A. (2017). Going Beyond Intention: Integrating Behavioral Expectation into the Unified Theory of Acceptance and Use of Technology. Journal of the Association for Information Science and Technology, 68(3), 623-637.

Mehrad, D., Mohammadi, S. (2017). Word of Mouth Impact on the Adoption of Mobile Banking in Iran. Telematics and Informatics, 34(7), 1351-1363. https://doi.org/10.1016/j.tele.2016.08.009

Mishra, V., Bisht, S.S. (2013). Mobile Banking in a Developing Economy: A Customer-centric Model for Policy Formulation. Telecommunications Policy, 37(6-7), 503-514.

Montazemi, A.R., Qahri-Saremi, H. (2015). Factors Affecting Adoption of Online Banking: A Meta-analytic Structural Equation Modeling Study. Information \& Management, 52(2), 210-226.

Mukherjee, R., Kumar, R., Sinha, A., Lama, Y., Saha, A.K. (2016). A Review on Synthesis, Characterization, and Applications of Nano Zero Valent Iron (nZVI) for Environmental Remediation. Critical Reviews in Environmental Science and Technology, 46(5), 443-466. https://doi.org/10.1080/10643389.2015.1103832

Mukhtar, M. (2015). Perceptions of UK Based Customers Toward Internet Banking in the United Kingdom. Journal of Internet Banking and Commerce, 20(1). https://doi.org/10.1007/978-3-531-92534-9_12

Nasri, W., Charfeddine, L. (2012). Factors Affecting the Adoption of Internet Banking in Tunisia: An Integration Theory of Acceptance Model and Theory of Planned Behavior. The Journal of High Technology Management Research, 23(1), 1-14.

Nor, K.M., Pearson, J.M. (2008). An Exploratory Study into the Adoption of Internet Banking in a Developing Country: Malaysia. Journal of Internet Commerce, 7(1), 29-73.

Nor, K.M., Shanab, E.A.A., Pearson, J.M. (2008). Internet Banking Acceptance in Malaysia based on the Theory of Reasoned Action. JISTEM-Journal of Information Systems and Technology Management, 5(1), 3-14. 
Nor, K. M., Sutanonpaiboon, J., Mastor, N.H. (2010). Malay, Chinese, and Internet Banking. Chinese Management Studies, 4 (2), 141-153. https://doi.org/10.1108/17506141011053069

Oliveira, T., Thomas, M., \& Espadanal, M. (2014). Information \& Management Assessing the Determinants of Cloud Computing Adoption: An Analysis of the Manufacturing and Services Sectors. Information \& Management, 51(5), 497-510. https://doi.org/10.1016/j.im.2014.03.006

Papies, D., Clement, M. (2008). Adoption of New Movie Distribution Services on the Internet. Journal of Media Economics, 21 (3), 131-157.

Phonthanukitithaworn, C., Sellitto, C., Fong, M. (2015). User Intentions to Adopt Mobile Payment Services: A Study of Early Adopters in Thailand. Journal of Internet Banking and Commerce, 20(1).

Pikkarainen, T., Pikkarainen, K., Karjaluoto, H., \& Pahnila, S. (2004). Consumer Acceptance of Online Banking: an Extension of the Technology Acceptance Model. Internet Research, 14(3), 224-235.

Poon, W.-C. (2007). Users' Adoption of E-banking Services: the Malaysian Perspective. Journal of Business \& Industrial Marketing, 23(1), 59-69.

Püschel, J., Afonso Mazzon, J., Mauro, C. Hernandez, J. (2010). Mobile Banking: Proposition of an Integrated Adoption Intention Framework. International Journal of Bank Marketing, 28(5), 389-409. https://doi.org/10.1108/02652321011064908

Ram, S., Sheth, J.N. (1989). Consumer Resistance to Innovations: the Marketing Problem and its Solutions. Journal of Consumer Marketing, 6(2), 5-14.

Riffai, M., Grant, K., Edgar, D. (2012). Big TAM in Oman: Exploring the Promise of On-line Banking, its Adoption by Customers and the Challenges of Banking in Oman. International Journal of Information Management, 32(3), 239-250.

Rodrigues, L.F., Oliveira, A., Costa, C.J. (2016). Does Ease-of-use Contributes to the Perception of Enjoyment? A Case of Gamification in E-banking. Computers in Human Behavior, 61, 114-126.

Rogers, E.M. (2003). Diffusion of Innovations Theory. New York: Free Press, 5th ed. https://doi.org/10.1111/j.14679523.1970.tb00071.x

Shaikh, A. A., \& Karjaluoto, H. (2014). Mobile Banking Adoption: A Literature Review. Telematics and Informatics, 32(1), 129142. https://doi.org/10.1016/j.tele.2014.05.003

Sharma, S.K., Govindaluri, S.M., Muharrami, S.M., Tarhini, A. (2017). A Multi-analytical Model for Mobile Banking Adoption: a Developing Country Perspective. Review of International Business and Strategy, 27(1), 133-148. https://doi.org/10.1108/ RIBS-11-2016-0074

Slade, E.L., Dwivedi, Y.K., Piercy, N.C., Williams, M.D. (2015). Modeling Consumers' Adoption Intentions of Remote Mobile Payments in the United Kingdom: Extending UTAUT with Innovativeness, Risk, and Trust. Psychology \& Marketing, 32(8), 860-873.

Sohail, M.S., Al-Jabri, I.M. (2014). Attitudes Towards Mobile Banking: Are There any Differences between Users and Nonusers? Behaviour and Information Technology, 33(4), 335-344. https://doi.org/10.1080/0144929X.2013.763861

Suh, B., Han, I. (2002). Effect of Trust on Customer Acceptance of Internet Banking. Electronic Commerce Research and Applications, 1(3-4), 247-263. https://doi.org/10.1016/S1567-4223(02)00017-0

Suh, B., Han, I. (2003). The Impact of Customer Trust and Perception of Security Control on the Acceptance of Electronic Commerce. International Journal of Electronic Commerce, 7(3), 135-161.

Sum Chau, V., Ngai, L.W.L.C. (2010). The Youth Market for Internet Banking Services: Perceptions, Attitude and behaviour. Journal of Services Marketing, 24(1), 42-60.

Sun, H., Zhang, P. (2006). The Role of Moderating Factors in User Technology Acceptance. International Journal of Human Computer Studies, 64(2), 53-78. https://doi.org/10.1016/j.ijhcs.2005.04.013

Tan, K.S., Chong, S.C., Loh, P.L., Lin, B. (2010). An Evaluation of E-banking and M-banking Adoption Factors and Preference in Malaysia: a Case Study. International Journal of Mobile Communications, 8(5), 507-527. 
Taylor, S., Todd, P. (1995). Assessing IT Usage : The Role of Prior Experience The Influence of Prior Experience. Management Information Systems, 19(December), 561-570.

Teo, T.S.H., Pok, S.H. (2003). Adoption of WAP-enabled Mobile Phones Among Internet Users. Omega, 31(6), 483-498.

Venkatesh, V., Davis, F.D. (2000). A Theoretical Extension of the Technology Acceptance Model: Four Longitudinal Field Studies. Management Science, 46(2), 186-204. https://doi.org/10.1287/mnsc.46.2.186.11926

Venkatesh, V., Thong, J. Y. L., \& Xu, X. (2012). Consumer Acceptance and Use of Information Technology: Extending the Unified Theory of Acceptance and Use of Technology. MIS Quarterly, 36(1), 157-178. https://doi.org/10.1111/j.15404560.1981.tb02627.x

Viswanath Venkatesh Michael G. Morris, G. B. D. F. D. D. (2003). User Acceptance of Information Technology: Toward a Unified View. MIS Quarterly, 27(3), 425-478. Retrieved from http://www.jstor.org/stable/30036540

Viswanath Venkatesh Michael G. Morris, G.B.D.F.D.D., Venkatesh, V., Morris, M.G., Davis, G.B., Davis, F.D. (2003). User Acceptance of Information Technology: Toward a Unified View. MIS Quarterly, 27(3), 425-478. https:// doi.org/10.1088/1751-8113/44/8/085201

Walker, R.H., Johnson, L.W. (2006). Why Consumers Use and do not Use Technology-enabled Services. Journal of Services Marketing, 20(2), 125-135.

Wang, Y.-S., Wang, Y.-M., Lin, H.-H., Tang, T.-I. (2018). Determinants of user Acceptance of Internet Banking: an Empirical Study. International Journal of Service Industry Management, 14(5), 501-519.

Weir, C.S., Douglas, G., Carruthers, M., Jack, M. (2009). User Perceptions of security, Convenience and Usability for Ebanking Authentication Tokens. Computers and Security, 28(1-2), 47-62. https://doi.org/10.1016/j.cose.2008.09.008

Ya-Yueh, S., Fang, K. (2004). The Use of a Decomposed Theory of Planned Behavior to Study Internet Banking in Taiwan. Internet Research, 14(3), 213-223. https://doi.org/10.1108/10662240410542643

Yang, J., Whitefield, M., Bhanot, R. (2005). E-banking in Rural Area-recent Trend and Development: a Case Study. Communications of the IIMA, 5(4), 9.

Yoon, H.S., Steege, L.M.B. (2013). Development of a Quantitative Model of the Impact of Customers' Personality and Perceptions on Internet Banking Use. Computers in Human Behavior, 29(3), 1133-1141.

Yousafzai, S., Pallister, J., Foxall, G. (2009). Multi-dimensional Role of Trust in Internet Banking Adoption. The Service Industries Journal, 29(5), 591-605.

Yu, P.L., Balaji, M.S., Khong, K.W. (2015). Building Trust in Internet Banking: a Trustworthiness Perspective. Industrial Management \& Data Systems, 115(2), 235-252.

Yuen, Y.Y., Yeow, P.H., Lim, N. (2015). Internet Banking Acceptance in the United States and Malaysia: a Cross-cultural Examination. Marketing Intelligence \& Planning, 33(3), 292-308. https://doi.org/10.1108/MIP-08-2013-0126

Zhou, T. (2011). An Empirical Examination of Users' Post-adoption Behaviour of Mobile Services. Behaviour \& Information Technology, 30(2), 241-250.

Zhou, T., Lu, Y., Wang, B. (2010). Integrating TTF and UTAUT to Explain Mobile Banking user Adoption. Computers in Human Behavior, 26(4), 760-767. 
Appendex 1: Measurement Items

\begin{tabular}{|c|c|c|}
\hline Constructs & Measurement Items & Source \\
\hline $\begin{array}{l}\text { Perceived } \\
\text { Usefulness }\end{array}$ & $\begin{array}{l}\text { PU1 Using mobile banking improves functioning of my banking activities. } \\
\text { PU2 Mobile banking allows me to manage my banking activities more efficiently. } \\
\text { PU3 Mobile banking enables me to complete my banking activities conveniently. } \\
\text { PU4 Mobile banking enables me to complete my banking activities more quickly. } \\
\text { PU5 Overall, I find mobile banking very useful for carrying out my banking activi- } \\
\text { ties. } \\
\text { PU6 In general, I find using mobile banking advantageous than branch banking. }\end{array}$ & $\begin{array}{l}\text { Giovanis et al. (2012); } \\
\text { Nor et al. (2010); } \\
\text { Cheng et al.(2006); } \\
\text { Manzano et al.(2009) }\end{array}$ \\
\hline $\begin{array}{l}\text { Perceived } \\
\text { ease of } \\
\text { use }\end{array}$ & $\begin{array}{l}\text { PEOU1 It is easy to use mobile banking } \\
\text { PEOU2 Learning to use mobile banking is easy. } \\
\text { PEOU3 The instructions provided on my mobile banking application are clear and } \\
\text { understandable. } \\
\text { PEOU4 I find it easy to remember how to use mobile banking. } \\
\text { PEOU5 Overall, I find the use of the mobile banking easy. }\end{array}$ & $\begin{array}{l}\text { Cheng et al. (2006); } \\
\text { Nor et al. (2010) Gio- } \\
\text { vanis et al. (2012); } \\
\text { Manzano et al. } \\
\text { (2009); }\end{array}$ \\
\hline $\begin{array}{l}\text { Perceived } \\
\text { Risk }\end{array}$ & $\begin{array}{l}\text { PR1 Using mobile banking subjects my banking account to potential fraud. } \\
\text { PR2 Using mobile banking subjects my banking account to financial risk. } \\
\text { PR3 I think using mobile banking puts my privacy at risk. } \\
\text { PR4 Hackers might take control of my bank account if I use mobile banking. } \\
\text { PR5 Using mobile banking will not fit well with my self-image. } \\
\text { PR6 mobile banking might not perform well and will create problems with my } \\
\text { bank account. } \\
\text { PR7 Using mobile banking exposes me to an overall risk. }\end{array}$ & $\begin{array}{l}\text { Featherman and Pav- } \\
\text { lou (2003) Curran }\end{array}$ \\
\hline $\begin{array}{l}\text { Subjective } \\
\text { norms }\end{array}$ & $\begin{array}{l}\text { SN1 People important to me support my use of mobile banking. } \\
\text { SN2 People who influence my behavior want me to use mobile banking instead of } \\
\text { any other alternative means. }\end{array}$ & Hung et al. (2003) \\
\hline Trust & $\begin{array}{l}\text { TRT1 I believe that mobile banking is trustworthy. } \\
\text { TRT2 I trust in mobile banking. } \\
\text { TRT3 I do not doubt the honesty of mobile banking. } \\
\text { TRT4 I feel assured that legal and technological structures adequately protect me } \\
\text { from problems on mobile banking. } \\
\text { TRT5 I Even if not monitored would trust mobile banking to do the job right. } \\
\text { TRT6 Mobile banking has the ability to fulfil its task. }\end{array}$ & $\begin{array}{l}\text { Gefen et al. (2003) } \\
\text { Gefen et al. (2003) } \\
\text { Gefen et al. (2003) } \\
\text { Gefen et al. (2003) }\end{array}$ \\
\hline FC & $\begin{array}{l}\text { FC } 1 \text { I have the resources necessary to use mobile banking. } \\
\text { FC } 2 \text { I have the knowledge necessary to use mobile banking. } \\
\text { FC } 3 \text { Mobile banking is compatible with other technologies I use. } \\
\text { FC } 4 \text { I can get help from others when I have difficulties using mobile banking }\end{array}$ & $\begin{array}{l}\text { Venkatesh et al. } \\
\text { (2012) Venkatesh et } \\
\text { al. (2012) Ven- } \\
\text { katesh et al. (2012) } \\
\text { Venkatesh et al. } \\
(2012)\end{array}$ \\
\hline
\end{tabular}




\begin{tabular}{|c|c|c|}
\hline $\begin{array}{l}\text { Website } \\
\text { usability }\end{array}$ & $\begin{array}{l}\text { WU1 I can easily navigate through the mobile application content } \\
\text { WU2 The structure and contents of mobile application is clear understandable } \\
\text { WU3 The experience that I had with mobile application was satisfactory } \\
\text { WU4 When navigating mobile application, I feel I am in control of what I can do } \\
\text { WU5 The organization of the contents, design and user friendliness make it easy } \\
\text { for me to know where I am when navigating it. }\end{array}$ & $\begin{array}{l}\text { (Barnes \& Vidgen, } \\
\text { 2002; and Jaruwachi- } \\
\text { rathanakul \& Fink, } \\
\text { 2005) }\end{array}$ \\
\hline Attitude & $\begin{array}{l}\text { ATT1 Using mobile banking service is a good decision. } \\
\text { ATT2 Using mobile banking service is a wise decision. } \\
\text { ATT3 Using mobile banking service is a positive step. } \\
\text { ATT4 I like to use mobile banking service. } \\
\text { ATT5 Overall, my attitude towards mobile banking is favorable. }\end{array}$ & $\begin{array}{l}\text { Cheng et al. (2006); } \\
\text { Suh and Han (2002); } \\
\text { Shih and Fang (2004); } \\
\text { Grabner-Kräuter and } \\
\text { Faullant (2008) }\end{array}$ \\
\hline $\begin{array}{l}\text { Behavioral } \\
\text { intention }\end{array}$ & $\begin{array}{l}\text { BI1 I intend to increase my use of the mobile banking service in the future. } \\
\text { BI2 I expect my transaction through mobile banking will increase in future. } \\
\text { BI3 I will add mobile banking to my favorite application. } \\
\text { BI4 I will encourage my friends and family to use mobile banking. } \\
\text { BI5 I will strongly recommend others to use mobile banking. }\end{array}$ & $\begin{array}{l}\text { Suh and Han (2002); } \\
\text { Walker and Johnson } \\
\text { (2006); Shih and Fang } \\
\text { (2004); Al- Sukkar } \\
\text { (2005) } \\
\text { (Suh \& Han, 2002) } \\
\text { (Walker \& Johnson, } \\
\text { 2006) } \\
\text { (Ya-Yueh \& Fang, } \\
\text { 2004) } \\
\text { (Al-Sukkar, 2005) }\end{array}$ \\
\hline
\end{tabular}

Source: Own elaboration 